\title{
Al-Qur'an dan Relasi Antar Umat Beragama; Diskursus Tentang Pendidikan Pluralisme Agama Di Indonesia*
}

\author{
(Al-Qur'an and Inter-Religious Relations; Discourse on the Education of \\ Religious Pluralism In Indonesia)
}

Kamarusdiana $^{1}$

Universitas Islam Negeri Syarif Hidayatullah Jakarta, Indonesia

doi $10.15408 /$ sjsbs.v5i3.9811

\begin{abstract}
:
The issue of diversity in religion is a social fact that has continued to experience conflict shocks lately. Not without reason, the conflict occurred on the grounds of sentiment towards other religions. This has an impact on the disruption of the stability of relations between religious groups. The discourse of religious pluralism is an alternative in overcoming this problem. Grounding religious pluralism is the right effort by not injuring religious values. Islam actually provides a clear explanation in the Koran about building a tolerant relationship in religion. This article will explain and provide an explanation of Islamic values in the Qur'an as an effort to develop religious pluralism that needs to be represented in a plural social context. It is hoped that with this, the harmony between religious people will be realized. Besides that, as a concrete follow-up, an education process is needed about the importance of tolerance in religion.
\end{abstract}

Keywords: Qur'an, Tolerance, Religious Pluralism, Harmony

\begin{abstract}
Abstrak
Isu keberagaman dalam beragama menjadi fakta sosial yang terus mengalami guncangan konflik belakangan ini. Bukan tanpa alasan, konflik tersebut terjadi dengan alasan sentimen terhadap agama lain. Hal ini berdampak pada terganggunya stabilitas hubungan antar umat beragama. Wacana pluralisme agama menjadi alternatif dalam mengatasi masalah tersebut. Membumikan pluralisme agama merupakan upaya yang tepat dengan tidak menciderai nilai-nilai agama. Islam sejatinya hadir memberikan penjelasan yang gamblang di dalam Alquran tentang membangun hubungan yang toleran dalam beragama. Tulisan ini akan memaparkan sekaligus memberikan penjelasan nilai-nilai keislaman yang ada dalam Alquran sebagai upaya mengembangkan pluralisme agama yang perlu direpresentasikan dalam konteks sosial yang plural. Diharapkan dengannya, akan terwujud kerukunan antar umat beragama. Selain itu, sebagai tindak lanjut yang konkrit dibutuhkan proses edukasi tentang pentingnya toleransi dalam beragama.
\end{abstract}

Kata Kunci: Alquran, Toleransi, Pluralisme Agama, Kerukunan

* Diterima: 12 September 2018, Revisi: 16 Oktober 2018, Dipublikasi 11 Desember 2018.

${ }^{1}$ Kamarusdiana adalah Doktor Bidang Hukum dan Dosen Tetap Fakultas Syariah dan Hukum UIN Syarif Hidayatullah Jakarta email: kamarusdiana@uinjkt.ac.id. 


\section{Pendahuluan}

Dewasa ini, isu pluralisme dalam beragama menjadi sorotan publik. Hal itu sebagai respon atas berbagai rasisme dan sikap intoleransi dalam beragama yang makin berkembang tanpa disadari. Namun, fakta ini memang tidak bisa dibantahkan karena memang mengingat di Indonesia sendiri sebagai negara yang memiliki keragaman yang kompleks juga terdapat konflik yang berkepanjangan. Misal saja, konflik komunal di Poso antara umat Muslim dan Kristiani, di mana konflik tersebut mengatasnamakan agama. Agama tanpa disadari telah menjadi penyulut konflik yang berkepanjangan. Karena pada dasarnya agama menjadi wilayah privasi yang cukup sensitif.

Meminjam istilah Ahmad Syafi'i Mufid, agama dianggap sebagai identitas suci dibandingkan dengan identitas sosial lainnya. ${ }^{2}$ Artinya, agama yang dipeluk seseorang dianggap sebagai sesuatu yang sakral, sehingga tidak seorangpun berhak merusak ataupun menciderai dan mengotori kesuciannya. Selain itu, dalam pandangan Quraish Shihab, agama dan kepercayaan dapat memancing emosi seseorang, di mana hal itu telah menjadi tabiat sebagai seorang manusia, karena pada dasarnya agama (keyakinan) bersemi dan bersumber dari dalam hati, sedangkan hati telah menjadi sumber emosi. ${ }^{3}$ Tentunya berbeda dengan pengetahuan yang mengandalkan akal dan pikiran, sehingga pengetahuan tidak mudah memancing emosi didalam hati.

Adanya konflik dalam beragama sejatinya lahir dari sikap eksklusivisme dalam beragama. Penerimaan sosial terhadap agama yang berbeda belum terlaksana secara bijak. Ajaran Islam sebagai agama yang ramah sejatinya memberikan tuntunan yang semestinya. Adanya fakta sejarah pluralisme beragama pada dasarnya telah menunjukkan manifestasi ajaran Islam Rahmatan Lil 'Alamin. Karena penyebaran Islam pada saat itu dilakukan dengan jalan damai. Namun, persoalan saat ini berakar pada minimnya pemahaman dan kesadaran tentang Islam Rahmatan Lil 'Alamin, di mana Islam sebagai agama yang ramah dan toleran terhadap sesama. Selama ini pemahaman tentang Islam hanya sebatas sebagai agama yang superior dibanding agama lain. Oleh sebab itu, perlunya melihat kembali esensi yang ada didalam Alquran dalam merespon pluralitas agama.

\section{Definisi Pluralisme Agama}

Adanya wacana pluralisme agama yang semakin berkembang selama ini. Maka, perlunya memahami pemaknaan atas pluralisme terlebih dahulu. Pluralisme berakar dari bahasa Latin, plures, yang berarti beberapa dengan

\footnotetext{
${ }^{2}$ Ahmad Syafi'i Mufid, Dialog Agama dan Kebangsaan, (Jakarta: Zikrul Hakim, 2001), hlm. 6

${ }^{3}$ M. Quraish Shihab, Membumikan Alquran: Memfungsikan Wahyu dalam Kehidupan, Jilid 2, (Jakarta: Lentera Hati, 2011), hlm. 77
} 
implikasi perbedaan. Sedangkan, secara terminologi pluralisme dapat diartikan sebagai paham (isme) atau sistem nilai yang mengakui adanya keberagaman atau kemajemukan. ${ }^{4}$ Sedangkan, pluralisme agama memiliki dua makna. Pertama, keberadaan kelompok yang berbeda-beda (keyakinan) dalam masyarakat. Kedua, kebijakan yang menjunjung perlindungan dan penghargaan terhadap perbedaan (keyakinan) tersebut. ${ }^{5}$

Selain itu, menurut Majelis Ulama Indonesia (MUI) dalam fatwanya menyatakan bahwa pluralisme adalah suatu paham yang mengajarkan bahwa semua agama sama dan karenanya kebenaran setiap agama adalah relatif. Oleh sebab itu, setiap pemeluk agama tidak boleh mengklaim bahwa hanya agamanya saja yang benar, sedangkan agama yang lain salah. Pluralisme agama juga mengajarkan bahwa setiap agama akan masuk dan hidup berdampingan di surga. ${ }^{6}$ Pluralisme agama menurut MUI tidak lagi dimaknai sebagai adanya kemajemukan agama, tetapi menyamakan semua agama. ${ }^{7}$ Namun disayangkan, fatwa ini cenderung menunjukkan adanya sikap eksklusivisme agama yang menyelimuti MUI, sehingga kemudian mengharamkannya. Tentu ini telah menjadi polemik tersendiri. Dikarenakan dapat menimbulkan prasangka negatif (negative stereotyping) yang dapat mengganggu kehidupan sosial-keagamaan.

Dalam konteks teologi, pluralisme mengandung makna harmoni, konvergensi, dan kompabilitas lintas tradisi agama, sehingga dari perspektif teologi pluralisme agama merupakan lawan dari ekslusivisme agama. ${ }^{8}$ Namun, terdapat pendapat lain yang menyatakan makna pluralisme agama adalah tidak mengakui semua agama benar, tetapi saling memberikan ruang yang sama terhadap agama atau aliran agar tetap berkembang di masyarakat. Hal ini menjadikan bentuk budaya dan agama harus diperlakukan sama dalam ruang publik.

Selain itu, penjelasan yang lebih rinci tentang pluralisme disampaikan oleh Profesor Diana Eck dari Harvard Divinity School, menurutnya pluralisme yang memimpin pluralism project berbeda dengan plurality atau diversity (keberagaman). Diversity dijelaskan oleh Diana Eck sebagai pluralitas yang alami, basic, simple, colorful, splendid, dan given sifatnya, atau dalam istilah santri disebut sebagai sunnatullah. Sedangkan, pluralisme dijelaskan oleh Diana Eck sebagai

\footnotetext{
${ }^{4}$ Ali Masykur Musa, Membumikan Islam Nusantara, (Jakarta: Serambi, 2014), hlm. 48

${ }^{5}$ Bagus Purnomo, "Toleransi Religius: Antara Pluralisme dan Pluralitas Agama dalam Perspektif Al-Qur'an", Suhuf, Vol. 6, No. 1, (2013), 83-103, hlm. 85

${ }^{6}$ Lihat Keputusan Fatwa Majelis Ulama Indonesia (MUI) No: 7/Munas VII/MUI/11/2005 Tentang Pluralisme, Liberalisme, dan Sekularisme Agama

77 Bagus Purnomo, "Toleransi Religius: Antara Pluralisme dan Pluralitas Agama dalam Perspektif Al-Qur'an", Suhuf, Vol. 6, No. 1, (2013), 83-103, hlm. 86

8 Sumanto Al-Qurtuby, Dialog Agama dan Peradaba, (Semarang: Elsa Press, 2016), hlm. 127
} 
sebuah proses pergumulan, yang bertujuan menciptakan sebuah masyarakat bersama atau common society. ${ }^{9}$

Dalam hal ini, pluralitas (kemajemukan) merupakan pemberian atau anugerah Tuhan (given). Sementara, pluralisme merupakan sebuah prestasi (achievement) bersama dari kelompok budaya dan agama yang berbeda untuk menciptakan common society. Kunci utama dalam memahami pluralisme adalah pergumulan kreatif-intensif terhadap fakta pluralitas atau dalam istilah Thomas Banchoff (Direktur Berkley Center for Religion, Peace, and World Affairs) disebut sebagai peaceful interaction. ${ }^{10}$

Patut dipahami adanya pluralisme agama tidak lepas dari fakta dan realitas sosial yang ada, sehingga tidak mungkin untuk mengingkarinya. Persepsi ini menjadi penting dikala adanya ketidakberimbangan informasi yang komprehenshif secara akademik di kalangan masyarakat. Setidaknya diperlukan informasi untuk dapat memberikan gambaran pemahaman yang bijak dan tepat tentang pluralisme agama, sehingga tidak ada lagi kesalahpahaman yang dapat berakibat fatal pada eksklusivisme agama.

\section{Historisasi Realitas Pluralisme Agama di Indonesia}

Sebagai bangsa yang besar, Indonesia telah memiliki rekam jejak sejarah yang panjang dan kompleks. Bukan sekadar sejarah perjuangan kemerdekaan melawan kolonialisme, yang notabennya sebagai sejarah membangun kekuasaan politik kenegaraan. Namun, Indonesia juga memiliki khazanah sejarah perjalanan dan perkembangan kepercayaan (agama) masyarakat Indonesia. Keberagaman etnis dan budaya yang ada di Indonesia juga telah memiliki distingsi catatan sejarah masing-masing dalam bingkai kearifan lokal (local wisdom) yang menarik.

Tidak dapat dipungkiri sebelum Islam masuk ke Indonesia pada abad ke7 ataupun dalam catatan sejarah lain dinyatakan pada abad ke-14. Bahkan, kalangan sejarawan menyakini bahwa proses Islamisasi, khususnya di Jawa terjadi pada periodisasi abad ke-14 hingga abad ke-16. Pada periodisasi abad tersebut Islam hadir dengan heroiknya, di mana Islam tidak lagi tampil sebagai community yang sporadis, tetapi sudah menjadi society yang terstruktur. ${ }^{11}$

Dalam historisasinya, jauh sebelum Islam hadir di Nusantara, masyarakat Indonesia telah memiliki berbagai kepercayaan lokal yang telah ada secara turun-temurun yang telah melekat dan bersemai bersama tradisi adat istiadat, termasuk pula adanya kepercayaan agama Hindu dan Budha yang telah dianut pada saat itu. Seperti diketahui agama Hindu dan Budha telah dianggap sebagai

\footnotetext{
${ }^{9}$ Sumanto Al-Qurtuby, Dialog Agama dan Peradaba, (Semarang: Elsa Press, 2016), hlm. 128

${ }^{10}$ Sumanto Al-Qurtuby, Dialog Agama dan Peradaba, (Semarang: Elsa Press, 2016), hlm. 127

${ }^{11}$ Sumanto Al-Qurtuby, Arus Cina Islam Jawa, (Semarang: Elsa Press, 2017), hlm. xxvi
} 
agama nenek moyang masyarakat Indonesia. Eksistensinya dapat dilihat pada kemegahan peninggalan sejarah keagamaan Hindu dan Budha, seperti Candi Prambanan dan Borobudor yang eksotikanya membuat dunia terpesona. Kedua candi tersebut berasal dari abad ke-8 hingga ke-9. Sampai saat ini pembangunan keduanya diasumsikan lahir dari kemelut persaingan dinasti-dinasti yang bersaing di Jawa Tengah, di mana Syailendra yang Budha dari basis mereka di Sumatera Selatan dan dinasti Hindu Jawa, yakni Sanjaya. Pelacakan sejarah atas kedua candi spektakuler tersebut menurut Anthony Reid menunjukkan adanya fakta koeksitensi damai dari kedua agama (Hindu dan Budha). ${ }^{12}$ Damai sosial dalam bingkai keberagaman kepercayaan pada masa silam menjadi simbol adanya pluralisme dalam beragama.

Periode berikutnya, Dinasti Yuan (Cina) yang notabennya memeluk agama Budhisme, Taoisme, dan Konfousianisme mendarat di pulau Jawa pada abad ke-12. Upaya kedatangan ke Nusantara dimaksudkan untuk berkoalisi dengan Raden Wijaya, di mana sebelumnya Prajurit Tartar dari Dinansti Yuan menghimpun serdadu Han dan Hui (etnis Tionghoa dan kelompok Tionghoa Muslim). Koalisi ini pada akhirnya melahirkan perluasan kerajaan Majapahit sebagai imperium regional. ${ }^{13}$ Dalam konteks ini, perbedaan agama tidak menjadi halangan untuk saling bekerjasama. Selain itu, dinasti Yuan juga dikenal memiliki toleransi agama yang tinggi kepada semua kalangan agama.

Islam lahir di tanah Nusantara tentu melewati proses yang sangat panjang dan mengalami persinggungan dengan kepercayaan agama lain dalam menyebarkannya. Penyebaran Islam diberbagai pelosok wilayah di Nusantara tidak lepas dari adanya peran Wali Songo. Mereka melakukan strategi menyebarkan agama Islam dengan cara yang sejuk dan damai. Karena mereka memahami kondisi masyarakat yang saat itu juga memiliki kepercayaannya sendiri-sendiri. Penyeberan Islam dengan cara yang sejuk dan damai demi mewujudkan adanya kenyamanan dan keamanaan antar pemeluk agama kepercayaan yang lain, sehingga tidak mengusik ataupun mengganggu kepercayaan yang lain. Hal itu dilakukan sebagai bukti bahwa Islam menghargai perbedaan dan pada dasarnya tidak ada paksaan dalam memeluk agama Islam.

Cara tersebut dilakukan untuk menunjukkan bahwa Islam adalah agama yang ramah, termasuk keramahan pada pemeluk agama kepercayaan yang lain. Spirit yang dibangun dalam Islam adalah spirit agama Rahmatan Lil 'Alamin. Artinya, Islam mampu menebarkan benih-benih kedamaian kepada siapa saja dalam mengimplementasikan ajaran teologisnya. Kepada umat manapun Islam akan memberikan kesejukan dan keramahannya, karena pada dasarnya Islam disebar luaskan bukan dengan jalan peperangan, tetapi dengan jalan kesejukan

\footnotetext{
${ }^{12}$ Anthony Reid, "Pluralisme Agama sebagai Tradisi Asia", dalam buku Bernard Adeney ed. Mengelola Keragaman di Indonesia, (Mizan: Bandung, 2015), hlm. 49

${ }^{13}$ Iwan Santoso, Tionghoa dalam Sejarah Kemiliteran, (Kompas, 2014), hlm. 1-7
} 
dan keramahan. Begitulah metode penyebaran Islam oleh Wali Songo agar mendapatkan simpatik dari nurani masyarakat pada saat itu, sehingga tanpa dipaksa sekalipun mereka akan menyatakan diri memeluk ajaran agama Islam.

Menilik pada pergolakan sejarah kemerdekaan Indonesia, di mana mampu melahirkan Pancasila, sebenarnya hal itu sebagai bentuk kompromi tiga pihak, yakni umat Islam, Muslim Abangan, kaum minoritas (selain agama Islam). Disisi lain, falsafah Bhinneka Tunggal Ika yang berasal dari puisi Mpu Tantular yang didalamnya merenungkan kesatuan esensial perbedaan yang ada dipermukaan, seperti diantara Budhisme, Saivisme, dan Islam yang baru datang, serta keberadaannya saat itu masih terpinggirkan. ${ }^{14}$ Fakta sejarah tersebut menunjukkan bahwa pluralisme beragama tidak dapat dinafikkan, sehingga keberadannya akan senantiasa mewarnai kerangka sosial masyarakat dalam berbangsa dan bernegara.

Realitas sejarah pluralisme agama di Indonesia memang tidak dapat dipungkiri. Menurut Ahmad Syafi'i Ma'arif pluralisme agama merupakan fakta sejarah. Bahkan, pluralisme di Indonesia memiliki basis sejarah dan ideologi yang kokoh, meskipun pada periode tertentu otoritariasnisme politis-religius berupaya mencabutnya. ${ }^{15}$ Selain itu, Anthony Reid mengemukakan pendapatnya bahwa Indonesia telah memiliki sejarah panjang dalam beragama, di mana orang-orang yang berbeda agama telah hidup berdampingan secara damai selama berabad-abad silam. Bahkan, dalam konteks Asia, Reid menyatakan orang Asia dalam menghadapi keragaman agama dan budaya dilakukan secara jauh lebih damai. ${ }^{16}$ Interaksi sosial yang damai menunjukkan adanya koeksistensi dalam kehidupan bermasyarakat.

\section{Islam dan Pluralisme Agama: Pandangan Toleransi Beragama dalam Alquran}

Pola kehidupan manusia dan interaksinya sangat variatif dan heterogen dalam konstruksi sosial. Kehidupan manusia tidaklah akan selalu sama dalam hal apapun. Karena manusia diciptakaan di atas perbedaan. Pada dasarnya penciptaan manusia yang berbeda-beda telah menjadi kehendak Allah Swt. Sebagaimana firman-Nya. sebagai berikut:

"Hai manusia, Sesungguhnya Kami menciptakan kamu dari seorang laki-laki dan seorang perempuan dan menjadikan kamu berbangsa - bangsa dan bersukusuku supaya kamu saling kenal-mengenal. Sesungguhnya orang yang paling mulia diantara kamu disisi Allah ialah orang yang paling taqwa diantara kamu.

\footnotetext{
${ }^{14}$ Anthony Reid, "Pluralisme Agama sebagai Tradisi Asia", dalam buku Bernard Adeney ed. Mengelola Keragaman di Indonesia, (Mizan: Bandung, 2015), hlm. 50

${ }^{15}$ Ahmad Syafi'i Ma'arif, "Pluralisme sebagai Fakta Sejarah", dalam buku Bernard Adeney ed. Mengelola Keragaman di Indonesia, (Mizan: Bandung, 2015), hlm. 79

${ }^{16}$ Anthony Reid, "Pluralisme Agama sebagai Tradisi Asia", dalam buku Bernard Adeney ed. Mengelola Keragaman di Indonesia, (Mizan: Bandung, 2015), hlm. 47
} 
Sesungguhnya Allah Maha mengetahui lagi Maha Mengenal." (Q.s. alHujurat/49: 13)

Asbabun Nuzul turunnya ayat di atas menurut Abu Dawud sebagaimana dikutip Ibnu 'Asyur berkaitan dengan perintah Nabi Saw. kepada Bani Bayadah yang berkulit putih agar menikahkan dengan sosok perempuan berkulit hitam, tetapi mereka menolaknya. ${ }^{17}$ Disisi lain, adanya perbedaan tersebut tentu bukan tanpa maksud. Artinya, dengan perbedaan diharapkan dapat terjalinnya kerja sama dan perlombaan dalam mencapai kebaikan bersama. Oleh sebab itu, perbedaan tidak sepatutnya dijadikan alasan untuk menimbulkan perselisihan yang dapat menimbulkan konflik berkepanjangan.

Dalam persoalan teologis antar sesama, Alquran memberikan penjelasan untuk tidak melakukan pemaksaan atas kepercayaan untuk memeluk agama Islam. Hal itu sebagaimana firman-Nya: "Tidak ada paksaan untuk (memasuki) agama (Islam); Sesungguhnya telah jelas jalan yang benar daripada jalan yang sesat...." (Q.s. al-Baqarah/2: 256).

Menurut Ibn 'Abbas Asbabun Nuzul ayat di atas turun berkenaan dengan seorang Anshar yang memiliki dua anak beragama Nasrani yang menginginkan kedua anaknya masuk Islam, kemudian turunlah ayat tersebut pasca menyampaikanya kepada Nabi Saw. ${ }^{18}$ Menurut Quraish Shihab tidak adanya paksaan tersebut demi menjaga rasa aman yang hakiki melalui iman didalam hati. ${ }^{19}$ Dalam konteks ini, jikalau seseorang dipaksa untuk masuk Islam tanpa keikhlasan nuraninya, tentu tidak akan terwujud rasa aman. Hal inilah yang menjadi fungsi utama agama.

Disurat lain Allah Swt. juga menjelaskan perlunya toleransi (tasamuh) atau sikap lapang dada untuk tidak memaksakan kepercayaannya kepada orang lain. Hal itu sebagaimana firman-Nya: "Dan Jikalau Tuhanmu menghendaki, tentulah beriman semua orang yang di muka bumi seluruhnya. Maka Apakah kamu (hendak) memaksa manusia supaya mereka menjadi orang-orang yang beriman semuanya ?." (Q.s. Yunus/10: 99)

Ayat di atas mengafirmasikan bahwa kepercayaan teologis (agama) hendaknya tidak perlu didapatkan dengan cara yang memaksa. Hal itu justru akan menciderai nilai-nilai agama itu sendiri. Dengan cara memaksa tentunya fungsi agama tidak akan dapat dirasakan, tetapi justru sebaliknya dapat menimbulkan hal yang negatif. Dalam konteks ini tentunya mengindikasikan urgensi dari sikap toleransi dalam beragama menjadi perlu dilaksanakan.

${ }^{17}$ Ibn'Asyur, Tafsir Al-Tahr wa Al-Tanwir, Jilid VI, (Tunis: Al-Dar Al-Tunisiyyah,1984), hlm.

18 Ibn Katsir. Tafsir Al-Qur'ân Al-'Azîm. Jilid II, (Giza: Mu'assasah Qordhoba-Maktabah Aulad Al-Syaikh li Al-Turats, 2000), hlm. 445

${ }^{19}$ M. Quraish Shihab, Membumikan Alquran: Memfungsikan Wahyu dalam Kehidupan, Jilid 2, (Jakarta: Lentera Hati, 2011), hlm. 76 
Disisi lain, mengenai adanya perbedaan antara manusia memang sejatinya sudah menjadi kehendak Allah Swt, sebagaimana firman-Nya: "Jikalau Tuhanmu menghendaki, tentu Dia menjadikan manusia umat yang satu, tetapi mereka Senantiasa berselisih pendapat." (Q.s. Hud/11: 118)

Seandainya Allah Swt. menghendaki kesatuan, niscaya diciptakan-Nya manusia tanpa akal budi, sehingga pastilah bersatu. ${ }^{20}$ Akan tetapi, Allah Swt. memberikan akal budi sebagai bentuk pemberian yang terbaik diantara makhluknya. Pemberian akal berfungsi sebagai penalaran atas makna kehidupan. Maka, perselisihan dan perbedaan pendapat musykil untuk ditolak dalam kehidupan sosial. Pada dasarnya, kesatuan pendapat dalam segala hal memang mustahil terjadi. Meskipun hakikatnya manusia itu sama. Bahkan, Allah Swt. telah memberikan penjelasan dalam firman-Nya: "Manusia itu adalah umat yang satu (setelah timbul perselisihan). Maka Allah mengutus Para Nabi, sebagai pemberi peringatan...." (Q.s. al-Baqarah/2: 213)

Ayat yang cukup populer dalam membicarakan perbedaan agama sekaligus bersikap tepat dalam beragama adalah surat al-Kafirun ayat 6, yakni: "Untukmu agamamu, dan untukkulah, agamaku." (Q.s. al-Kafirun/109: 6)

Pada dasarnya Asbabun Nuzul surat al-Kafirun berkaitan dengan permintaan kaum Quraish untuk melakukan ibadah secara bergantian, tetapi Nabi Saw. menolak melakukannya. Dalam hal ini, Islam memberikan gambaran bahwa keimanan telah menjadi sesuatu yang pasti, di mana tidak boleh dipermainkan. Dalam pandangan Quraish Shihab hal keimanan yang ada didalam hati bersifat absolut, tetapi tidak menuntut pernyataan atau kenyataan di luar bagi yang tidak menyakininya. ${ }^{21}$ Ayat ini sejatinya memberikan gambaran toleransi dalam beragama, dengan tidak mencampurkan urusan keimanan antara agama yang satu dan yang lain. Namun, tetap memberikan sikap dan ruang untuk menghargai perbedaan keyakinan, sehingga tidak saling menimbulkan perselisihan yang dapat mengganggu stabilitas sosial.

Toleransi merupakan awal adanya kerukunan, tanpa adanya toleransi tidak mungkin terjalin sikap saling menghormati, saling mengasihi, dan gotong royong antar umat beragama. ${ }^{22}$ Adanya sikap saling memberikan ruang untuk mengekspresikan keberagamaan setiap umat beragama akan memberikan wajah kesejukan toleransi dalam beragama. Hal itu yang secara berkelanjutan memberikan kesejukan ajaran agama yang dalam interaksi kehidupan sosial.

\footnotetext{
${ }^{20}$ M. Quraish Shihab, Membumikan Alquran: Fungsi dan Peran Wahyu dalam Kehidupan, Jilid 1, (Bandung: Mizan, 1999), hlm. 222

${ }^{21}$ M. Quraish Shihab, Membumikan Alquran: Fungsi dan Peran Wahyu dalam Kehidupan, Jilid 1, (Bandung: Mizan, 1999), hlm. 222

${ }^{22}$ Anita Khusnun Nisa dan M. Wahid Nur T., “Kajian Kritis Tentang Toleransi Beragama dalam Islam," Al-Hikmah, Vol. 2, No, 2 (2016), 1-12, hlm. 2
} 


\section{Al-Qur'an dan Cita-Cita Kerukunan Antar Umat Beragama}

Islam sebagai agama yang ramah telah menunjukkan nilai-nilai ajaran yang inklusif. Nilai-nilai universal Islam yang luhur dengan konsep Rahmatan Lil 'Alamin memberikan distingsi tersendiri. Karena Islam tidak memihak pada Muslim saja, tetapi juga memberikan jaminan sosial pada pemeluk agama lain. Menurut KH. Hasyim Muzadi rahmat Allah Swt. untuk seluruh mahluk-Nya, termasuk non-Muslim. Sedangkan, rahim-Nya hanya diperuntukkan bagi-bagi orang yang taat kepada-Nya. ${ }^{23}$

Fungsi dan tujuan dari agama adalah memberikan rasa aman dan nyaman, baik secara personal maupun kolektif dalam kehidupan sosial. Dalam pandangan Quraish Shihab iman dan aman memiliki kaitan yang erat. Rasa aman diperoleh melalui keyakinan tentang sesuainya sikap manusia dengan kehendak dan petunjuk Allah Swt. ${ }^{24}$ Implikasi ini menjadi penting demi mewujudkan sikap inklusif pada kesalehan personal, sehingga dapat melahirkan semangat toleransi dalam beragama demi terwujudnya kerukunan yang berdasarkan pada kedamaian dan keamanan dalam beragama. Pada dasarnya Allah Swt. juga telah memberikan seruan untuk hidup damai dan aman, sebagaimana firman-Nya: "Allah menyeru (manusia) ke darussalam (surga), dan menunjuki orang yang dikehendaki-Nya kepada jalan yang Lurus (Islam)." (Q.s. Yunus/10: 25).

Menurut Quraish Shihab arti kalimat darussalam adalah tempat yang penuh kedamaian dan keselamatan. ${ }^{25}$ Seruan tersebut bukan hanya menunjuk kepada Muslim, tetapi manusia pada umumnya, sehingga sepatutnya setiap umat beragama untuk saling menciptakan rasa damai dan aman demi kerukunan umat beragama itu sendiri. Kerukunan beragama menjadi simbol penting kesalehan sosial dalam melaksanakan ajaran agama.

Dalam konteks memelihara rasa damai dan aman, Alquran memerintahkan untuk tidak saling memaki, menghina agama, dan sesembahan siapapun, sebagaimana firman-Nya:

“Dan janganlah kamu memaki sembahan-sembahan yang mereka sembah selain Allah, karena mereka nanti akan memaki Allah dengan melampaui batas tanpa pengetahuan. Demikianlah Kami jadikan Setiap umat menganggap baik pekerjaan mereka. kemudian kepada Tuhan merekalah kembali mereka, lalu Dia memberitakan kepada mereka apa yang dahulu mereka kerjakan." (Q.s. alAn'am/6: 108)

${ }^{23}$ Muhammad Makmun Rasyid, "Islam Rahmatan Lil 'Alamin Perspektif KH. Hasyim Muzadi," Episteme, Vol.11, No.1, (Juni 2016), 193-116, hlm. 104

${ }^{24}$ M. Quraish Shihab, Membumikan Alquran: Fungsi dan Peran Wahyu dalam Kehidupan, Jilid 1, (Bandung: Mizan, 1999), hlm. 219

${ }_{25}$ M. Quraish Shihab, Membumikan Alquran: Memfungsikan Wahyu dalam Kehidupan, Jilid 2, (Jakarta: Lentera Hati, 2011), hlm. 74-75 
Al-Wahidi menjelaskan Asbabun Nuzul ayat di atas, di mana saat itu terjadi ultimatum dari kaum Musyrik kepada Nabi Saw. pasca kaum Muslim menghina sesembahan mereka. ${ }^{26}$ Larangan memaki-maki tuhan-tuhan dari agama lain guna memelihara kesucian agama itu sendiri, serta demi berlangsungnya hubungan kerukunan yang harmonis antar umat umat beragama. Disisi lain, Alquran juga mengingatkan pentingnya bekerja sama dalam kebajikan dan pemeliharaan tempat-tempat suci (ibadah), sebagaimana ditegaskan dalam firman-Nya:

“....Sekiranya Allah tiada menolak (keganasan) sebagian manusia dengan sebagian yang lain, tentulah telah dirobohkan biara-biara Nasrani, gereja-gereja, rumah-rumah ibadat orang Yahudi dan masjid- masjid, yang di dalamnya banyak disebut nama Allah. Sesungguhnya Allah pasti menolong orang yang menolong (agama)-Nya...." (Q.s. al-Hajj/22: 40)

Pandangan Quraish Shihab terhadap ayat di atas dipahami bahwa Allah Swt. tidak menghendaki kehancuran rumah-rumah ibadah, sehingga sudah menjadi kewajiban umat Islam untuk senantiasa menjaganya. Oleh sebab itu, umat Islam bukan saja memelihara masjid, tetapi juga rumah-rumah ibadah umat agama lainnya. Selain itu, pakar-pakar tafsir dan hukum Islam juga melarang merobohkan gereja-geraja adz-Dzimmah, atau menjualnya kepada yang lain, demikian juga berlaku bagi rumah peribadatan umat yang lain. ${ }^{27}$

Selain itu, Islam juga memberikan tuntunan agar dapat memberikan jaminan keamanan bagi umat agama lain. Jaminan ini berdasarkan asas kemanausiaan, demi menjaga harkat dan martabat seorang manusia, sehingga hal ini akan melekat dalam nurani secara sendirinya. Hal ini dipertegas dalam firman-Nya: "Dan jika seorang diantara orang-orang musyrikin itu meminta perlindungan kepadamu, Maka lindungilah ia supaya ia sempat mendengar firman Allah, kemudian antarkanlah ia ketempat yang aman baginya...." (Q.s. al-Taubah/9: 6)

Menurut Muhammad Sayyid Thanthawi, Mufti Mesir dan Syaikh alAzhar, menerangkan adanya pemberian rasa aman dan perlindungan merupakan puncak yang diajarkan Islam kepada kaum Musyrik. ${ }^{28}$ Selain itu, ayat di atas juga bermaksud menjamin perlindungan, di mana tidak hanya menyangkut pada nyawa dan harta, tetapi juga kepercayaan dan keyakinan mereka. Begitu luas perhatian Islam kepada agama lain. Hal ini menjadi nilai luhur yang dimiliki Islam dalam merespon perbedaan agama.

Spirit Islam dalam memandang umat selain Islam memberikan corak yang cukup inklusif dan holisitik. Penjelasan berbagai ayat dalam Alquran

${ }^{26}$ Al-Wahidi, Asbab Al-Nuzul, (Al-Dammam: Dar Al-Ishlah, 1996), hlm. 221

${ }^{27}$ M. Quraish Shihab, Membumikan Alquran: Memfungsikan Wahyu dalam Kehidupan, Jilid 2, (Jakarta: Lentera Hati, 2011), hlm. 78-79

${ }^{28}$ M. Quraish Shihab, Membumikan Alquran: Memfungsikan Wahyu dalam Kehidupan, Jilid 2, (Jakarta: Lentera Hati, 2011), hlm. 83 
sekiranya mampu memberikan edukasi agama positif bahwansanya Islam tidak hanya memberikan toleransi dalam beragama, tetapi juga menjamin ketenangan, keamanan, dan kesejahteraan umat lain. Tentunya demi terciptanya kerukunan antar umat beragama, sehingga sudah semestinya saling memberikan timbal balik antara agama yang satu dengan yang lain dalam konteks bermasyarakat.

\section{Membumikan Spirit Pendidikan Pluralisme Agama}

Demi suksesnya implementasinya pluralisme agama tidak dapat terlaksana begitu saja tanpa melalui proses pembudayaan. Proses ini merupakan salah satu bentuk pendidikan pluralisme yang perlu diwacanakan sejak dini, di mana pada dasarnya pendidikan tidak bisa dilepaskan dari proses pembiasaan dan pembudayaan. Pendidikan juga mempunya arti sebagai bagian dari kebudayaan nasional. ${ }^{29}$ Azyumardi Azra menyatakan pendidikan tidak hanya sekadar latihan fisik, tetapi juga mental dan moral bagi individu-individu, agar mereka menjadi manusia yang berbudaya. ${ }^{30}$

Pengetahuan akan pluralisme agama merupakan sesuatu yang urgen untuk saat ini. Hal itu untuk merespon maraknya isu kekerasan dan konflik antar agama belakangan ini mendapat cukup sorotan. Bahkan, konflik dan kekerasan atas nama agama yang berkepanjangan memunculkan adanya istilah agama radikal dalam pandangan James Veitch sebagai respon konflik sosial dan politik. ${ }^{31}$ Namun, Azyumardi Azra menolak pandangan penyebutan agama radikal. Menurut Azra tidak boleh mengaitkan agama tertentu dengan kekerasan, apalagi melabelinya dengan agama radikal. ${ }^{22}$

Adanya konflik dan kekerasan atas nama agama menjadikan nilai-nilai kesucian agama terkotori. Disini perlunya mengembalikan eksistensi hakikat agama, bahwa semua agama menyebarkan kedamaian. Oleh sebab itu, edukasi tentang toleransi menjadi solusi alternatif sebagai langkah preventif sekaligus rehabilitasi sosiologis dan psikologis pasca konflik. Islam juga memberikan tuntunan pentingnya proses pendidikan. Bahkan, pendidikan Islam dianggap sebagai pendidikan moral. Karena didalam Islam moral yang baik akan mendorong akhlak dan kesalehan personal.

Spirit pendidikan akan pluralisme agama dapat dimulai sejak masa anak. Namun, secara garis besar pendidikan pluralisme dapat diimplementasikan dalam dua hal. Pertama, lingkungan pendidikan. Dalam beberapa tahun terakhir

\footnotetext{
${ }^{29}$ H.A.R. Tilaar, Kaleidoskop Pendidikan Nasional, (Jakarta: Kompas, 2012), hlm. 1095

30 Azyumardi Azra, Esei-Esei Intelektual Muslim dan Pendidikan Islam, (Jakarta: Logos Wacana Ilmu, 1998), hlm. 3

31 James Veitch, "Pluralisme dan Keragaman di Era Radikalisme Keagamaan", dalam buku Bernard Adeney ed. Mengelola Keragaman di Indonesia, (Mizan: Bandung, 2015), hlm. 178

32 Azyumardi Azra, "Kekerasan dan Terorisme Terkait Agama", dalam buku Bernard Adeney ed. Mengelola Keragaman di Indonesia, (Mizan: Bandung, 2015), hlm. 207
} 
lembaga pendidikan mendapat sorotan negatif. Hal itu dikarenakan menurut penelitian Pusat Pengkajian Islam dan Masyarakat (PPIM) UIN Jakarta (2016) tentang: "Diseminasi Paham Eksklusif dalam Pendidikan Islam," menemukan bahwa paham intoleransi keagamaan masih ditemukan melalui penyajian buku ajar di sekolah yang kurang mengedepankan aspek dialogis (Abdallah, 2016). Oleh sebab itu, dibutuhkan perhatian dan upaya lebih dalam membuat buku ajar yang sesuai dengan nilai-nilai humanisasi. Namun, dibutuhkan pula pengajar agama yang berkompeten dalam keislaman. Pada sekolah formal tentunya anak-anak sedini mungkin diajarkan tentang keberagaman yang ada di masyarakat tanpa memberikan stigma negatif atas perbedaan tersebut, khususnya perbedaan agama. Selanjutnya, pola sikap untuk saling menghargai dan bertoleransi juga perlu diajarkan.

Kedua, lingkungan sosial. Disini peran keluarga menjadi sentral sekaligus pendidikan awal dalam memberikan arahan bersikap menghargai dan bertoleransi terhadap perbedaan. Lingkungan sosial dan masyarakat juga perlu berada dalam iklim yang kondusif, sehingga proses edukasi akan toleransi menjadi lebih mudah diimplementasikan. Pentingnya toleransi perlu diinternalisasi dalam aktivitas ritual keagamaan yang bersifat sosial (dilakukan bersama). Dalam hal ini, dilakukan dengan cara berdakwah, di mana dilakukan dengan cara persuasif. Namun, terdapat instrumen penting dalam memberikan dakwah, yakni dengan menyiapkan pendakwah yang arif sekaligus inklusif, bukan eksklusif, kemudian memilih materi dakwah yang menyejukkan, serta dakwah perlu dalam kerangka paradigma transformasi sebagai modal menuju kerjasama antar umat beragama. ${ }^{33}$ Selain itu, para pendakwah dan pemuka agama juga perlu memberikan ruang konsultasi antar umat secara dialogis. ${ }^{34}$

Pengetahuan akan pentingnya toleransi beragama juga berawal dari pemahaman akan ajaran agama. Oleh sebab itu, perlunya menghindari skripturalisme agama, di mana hanya menempatkan agama hanya sebatas skriptural (teks-teks keagamaan). ${ }^{35} \mathrm{Hal}$ ini menjadikan hanya sebatas pada literal, yang hanya menekankan dimensi luarnya, yang secara lebih jauh berdampak pada terabaikannya dimensi kontekstual yang ada di masyarakat.

Dalam memberikan semangat pendidikan pluralisme agama, maka perlu menekankan pada aspek konstektual didalam masyarakat. Karena pemahaman yang literal akan cenderung rigid, sehingga sangat memungkinkan menyudutkan, bahkan menyalahkan orang lain yang berbeda. Dalam menerapkannya tentu harus dilakukan secara bersamaan dengan antar umat

${ }^{33}$ Nur Setiawati, “Tantangan Dakwah dalam Perspektif Kerukunan Antar Umat Beragama," Dakwah Tabligh, Vol. 13, No. 2, (Desember, 2012), 259-267 hlm. 265

${ }^{34}$ Ahmad Syafi'i Mufid, Dialog Agama dan Kebangsaan, (Jakarta: Zikrul Hakim, 2001), hlm.

40

${ }^{35}$ Bahtiar Effendy, "Islam Liberal dalam Arus Peradaban Global," dalam Halid Alkaf, Quo Vadis: Liberalisme Islam Indonesia, (Jakarta: Kompas, 2011), hlm. xx 
beragama agar terjadi simbiosis yang baik, sehingga akan sama-sama memberikan inklusivitas demi kerukunan antar umat beragama.

Interaksi antar umat beragam dalam menyebarkan kesejukan beragama merupakan bentuk dialogis yang tepat. Upaya dialog antar agama tidak hanya menyelesaikan masalah internal, tetapi juga menguatkan kembali simpul hubungan antar agama. Setidaknya proses pendidikan pluralisme agama nantinya dapat melahirkan dialog-dialog antar agama yang komprehensif dan holistik tanpa harus menciderai nilai-nilai keagamaan masing-masing.

\section{Kesimpulan}

Membudayakan pluralisme agama bukan seuatu yang mudah, tetapi bukan juga sesuatu yang mustahil. Sudah sepatunya umat beragama saling bersikap menghargai secara teologis. Hal itu bertujuan untuk mewujudkan adanya sikap yang inklusif dan moderat antar umat beragama, di mana secara lebih jauh dapat menghindarkan dari lahirnya konflik-konflik atas nama agama.

\section{Daftar Pustaka}

Abdallah. Pendidikan Agama dan Akar Radikalisme. Opini harian Koran Tempo, edisi, 13 September 2016

Aji, Ahmad Mukri. Urgensi Maslahat Mursalah Dalam Dialektika Pemikiran Hukum Islam, Bogor: Pustaka Pena Ilahi, 2012.

Al-Qurtuby, Sumanto. Arus Cina Islam Jawa. Semarang: Elsa Press. 2017

Al-Qurtuby, Sumanto. Dialog Agama dan Peradaba. Semarang: Elsa Press. 2016

Al-Wahidi. Asbab Al-Nuzul. Al-Dammam: Dar Al-Ishlah.1996

Asyur, Ibn'.Tafsir Al-Tahr wa Al-Tanwir Jilid VI. Tunis: Al-Dar Al-Tunisiyyah.1984

Azra, Azyumardi. "Kekerasan dan Terorisme Terkait Agama". Dalam buku Bernard Adeney ed. Mengelola Keragaman di Indonesia. Mizan: Bandung. 2015

Azra, Azyumardi. Esei-Esei Intelektual Muslim dan Pendidikan Islam. Jakarta: Logos Wacana Ilmu. 1998

Effendy, Bahtiar. "Islam Liberal dalam Arus Peradaban Global." Dalam Halid Alkaf, Quo Vadis: Liberalisme Islam Indonesia. Jakarta: Kompas. 2011

Katsir, Ibn. Tafsir Al-Qur'ân Al-'Azîm Jilid II. Giza: Mu'assasah QordhobaMaktabah Aulad Al-Syaikh li Al-Turats. 2000

Keputusan Fatwa Majelis Ulama Indonesia (MUI) No: 7/Munas VII/MUI/11/2005 Tentang Pluralisme, Liberalisme, dan Sekularisme Agama 
Ma'arif, Ahmad Syafi'i. "Pluralisme sebagai Fakta Sejarah", Dalam buku Bernard Adeney ed. Mengelola Keragaman di Indonesia. Mizan: Bandung. 2015

Mufid, Ahmad Syafi'i. Dialog Agama dan Kebangsaan. Jakarta: Zikrul Hakim. 2001

Musa, Ali Masykur. Membumikan Islam Nusantara. Jakarta: Serambi. 2014

Nisa, Anita Khusnun dan M. Wahid Nur T. "Kajian Kritis Tentang Toleransi Beragama dalam Islam." Al-Hikmah. Vol. 2. No. 2 (2016).

Purnomo, Bagus. “Toleransi Religius: Antara Pluralisme dan Pluralitas Agama dalam Perspektif Al-Qur'an", Suhuf. Vol. 6. No. 1. (2013). 83-103

Rasyid, Muhammad Makmun. "Islam Rahmatan Lil 'Alamin Perspektif KH. Hasyim Muzadi.” Episteme. Vol.11. No.1. (Juni 2016).

Reid, Anthony. "Pluralisme Agama sebagai Tradisi Asia". Dalam buku Bernard Adeney ed. Mengelola Keragaman di Indonesia. Mizan: Bandung. 2015

Santoso, Iwan. Tionghoa dalam Sejarah Kemiliteran. Kompas. 2014

Setiawati, Nur. "Tantangan Dakwah dalam Perspektif Kerukunan Antar Umat Beragama." Dakwah Tabligh. Vol. 13. No. 2. (Desember. 2012),.259-267

Shihab, M. Quraish. Membumikan Alquran: Fungsi dan Peran Wahyu dalam Kehidupan Jilid 1, Bandung: Mizan. 1999

Shihab, M. Quraish. Membumikan Alquran: Memfungsikan Wahyu dalam Kehidupan Jilid 2. Jakarta: Lentera Hati. 2011

Sopyan, Yayan. "Menyoal kebebasan beragama dan penodaan agama di Indonesia (Telaah atas Putusan MK No. 140/PUU-VII/2009)," dalam Jurnal Cita Hukum, Vol. 3, No. 2 (2015).

Tilaar, H.A.R. Kaleidoskop Pendidikan Nasional. Jakarta: Kompas. 2012

Veitch, James. "Pluralisme dan Keragaman di Era Radikalisme Keagamaan". Dalam buku Bernard Adeney ed. Mengelola Keragaman di Indonesia. Mizan: Bandung. 2015.

Yunus, Nur Rohim. Restorasi Budaya Hukum Masyarakat Indonesia, Bogor: Jurisprudence Press, 2012. 